\title{
INTEGRASI MODEL KANO KE DALAM QFD UNTUK MENGOPTIMALKAN KUALITAS PERGURUAN TINGGI DI PROVINSI RIAU
}

\section{INTEGRATION OF KANO MODEL INTO QFD TO OPTIMIZE HIGH QUALITY OF HIGHER EDUCATION IN PROVINCE OF RIAU}

\author{
Hafidzah Nurjannah ${ }^{1}$, Desy Mardianty ${ }^{2}$ \\ Fakultas Ekonomi, Universitas Islam Riau ${ }^{1,2}$ \\ hafidzahnurjannah@eco.uir.ac.id ${ }^{1}$
}

\begin{abstract}
Higher Education has become a need for formal education as a strategic sector which is expected to produce quality intellectual graduates who are competitive. The competitive situation among universities requires educational institutions to pay attention to the quality of their education so that they are able to excel in the competition. To be able to compete, universities must improve their quality by providing attributes that are a priority for student needs. The purpose of this study is to optimize the quality of Private Universities in Riau Province by providing several technical responses. The population in this study were all active students of Private Universities in Riau Province and the total sample of 397 respondents using probability sampling techniques. This study uses the Kano Model and the Quality Function Deployment (QFD) approach as an integration tool that can help collect student voices as customers $(V o C)$ and produce a priority matrix of needs and technical responses in the form of House of Quality (HoQ). The results of this study found 7 (seven) priority priorities for students, including the online KRS filling process that is very easy for students, academic information easily obtained, fast, and accurate, academic administration staff are reliable / responsive in providing services, adequate health facilities, Adequate library facilities (books, proceeding journals, and articles), Easy internet access, and adequate computer labor. From this research, Private Universities can take several steps to optimize quality such as improving internet facilities, monitoring academic rules, and monitoring the learning process.
\end{abstract}

Keywords : Kano Model, House of Quality (HoQ), Quality Function Deployment (QFD), Quality

\begin{abstract}
ABSTRAK
Perguruan Tinggi telah menjadi suatu kebutuhan akan pendidikan formal sebagai sektor strategis yang diharapkan sehingga menghasilkan lulusan intelektual yang bermutu serta berdaya saing. Keadaan persaingan yang kompetitif antar perguruan tinggi menuntut lembaga pendidikan memperhatikan mutu pendidikannya sehingga mampu serta unggul dalam persaingan tersebut. Untuk dapat bersaing, Perguruan Tinggi harus meningkatkan kualitasnya dengan cara memberikan atribut yang menjadi prioritas kebutuhan mahasiswa. Tujuan penelitian ini untuk mengoptimalkan kualitas Perguruan Tinggi Swasta di Provinsi Riau dengan memberikan beberapa tanggapan teknis. Populasi dalam penelitian ini adalah seluruh mahasiswa aktif Universitas Swasta yang
\end{abstract}


ada di Provinsi Riau dan jumlah sampel sebanyak 397 responden dengan menggunakan teknik probability sampling. Penelitian ini menggunakan Model Kano dan pendekatan Quality Function Deployment (QFD) sebagai alat integrasi yang dapat membantu mengumpulkan suara mahasiswa sebagai pelanggan (VoC) dan menghasilkan matriks prioritas kebutuhan dan respon teknis dalam bentuk House of Quality (HoQ). Hasil penelitian ini menemukan 7 (tujuh) yang menjadi prioritas kebutuhan mahasiswa, diantaranya Proses pengisian KRS online yang sangat mudah bagi mahasiswa, Informasi akademik mudah diperoleh, cepat, dan akurat, Staff administrasi akademik handal/cepat tanggap dalam memberikan pelayanan, Fasilitas kesehatan memadai, Fasilitas perpustakaan yang memadai (buku, jurnal proceeding, dan artikel), Kemudahan akses interrnet, dan Labor komputer yang memadai. Dari penelitian ini, Perguruan Tinggi Swasta dapat melakukan beberapa langkah untuk mengoptimalkan kualitas seperti peningkatan fasilitas internet, monitoring aturan akademik, dan monitoring proses pembelajaran.

Kata Kunci : Kano Model, House of Quality (HoQ), Quality Function Deployment (QFD), Quality

\section{PENDAHULUAN}

Kualitas sumber daya manusia memainkan peran penting dalam pertumbuhan dan perkembangan masyarakat di mana kualitas seseorang dapat diperkaya dengan pendidikan yang berkualitas tinggi yang telah disediakan oleh Perguruan Tinggi (AlBashir 2016). Untuk itu, pendidikan tinggi menjadi bagian nyata dari proses globalisasi di mana pasokan (alumni) dan permintaan (dunia kerja) dicocokkan (Qureshi et al., 2014). Selain itu, konfrontasi dengan banyak perubahan dan tantangan yang cepat serta meningkatnya persaingan antar organisasi telah memaksa lembaga pendidikan tinggi untuk lebih dinamis dalam fokus pada mahasiswa sehingga dapat meningkatkan kredibilitas lembaga pendidikan tinggi (Arefi et al., 2012)..

Pesatnyaperkembangan perguruan Tinggi di Indonesia semakin membuat kondisi persaingan dalam merebut pangsa pasar yang semakin ketat (Suhendar 2015). Perguruan tinggi dituntut untuk dapat melahirkan ilmuwan yang mandiri dan inovatif untuk membangun masyarakat. Inovasi yang dikembangkan perguruan tinggi perlu sesuai dengan kebutuhan hidup masyarakat yang cenderung berubah (Sunder \& Antony 2018). Hal ini dikarenakan perguruan tinggi sebagai institusi yang memberikan pelayanan jasa dibidang pendidikan. Bidang pendidikan merupakan salah satu faktor yang memegang peranan penting dalam perkembangan ilmu pengetahuan dan menciptakan sumber daya manusia (SDM) yang mampu menghadapi pasar nasional maupun global sehingga perguruan tinggi harus siap bersaing bagi lulusannya menempati pasar kerja (Bangun et al., 2013). Perguruan tinggi yang dapat meningkatkan kualitas kelembagaan dan lulusan berintelektual yang berkualitas sehingga bermanfaat bagi masyarakat merupakan kunci sukses untuk memenangkan persaingan antar perguruan tinggi.

Beberapa tahun terakhir, kualitas telah menjadi topik diskusi yang penting di kalangan institusi pendidikan tinggi (Ngurah et al., 2016). Salah satu cara untuk meningkatkan kualitas pendidikan tinggi dengan menentukan atribut yang paling penting untuk meningkatkan layanan yang dapat 
membantu memenuhi kebutuhan serta harapan mahasiswa hari ini dan besok (Yang et al., 2010).

\section{METODE PENELITIAN}

Penelitian ini menggunakan analisis kuantitatif di mana objek penelitian ini adalah mahasiswa aktif pada Universitas Swasta di Provinsi Riau sebanyak tujuh Universitas dengan jumlah 397 mahasiswa sebagai responden. Teknik pengambilan sampel dalam penelitian ini adalah dengan menggunakan sampel random (acak). Penelitian ini dianalisis dengan menggunakan Model Kano lalu di integrasikan ke dalam Quality Function Deployment (QFD).

\section{Analisis House of Quality (HOQ)}

Beberapa langkah yang digunakan dalam mengintegrasikan Model Kano dan HOQ adalah sebagai berikut:

1. Membuat item pertanyaan dalam bentuk kuesioner yang terdiri dari pertanyaan fungsional dan pertanyaan disfungsional.

2. Dengan menggabungkan pertanyaan fungsional dan disfungsional, maka tipe persyaratan suatu produk dapat diklasifikasikan sesuai tabel 3 berikut:

\section{Tabel 1. Tabel Evaluasi Kano}

\begin{tabular}{|c|c|c|c|c|c|c|}
\hline \multirow{2}{*}{\multicolumn{2}{|c|}{ Sebutuhan Konsumen }} & \multicolumn{5}{|c|}{ Disfungsional } \\
\hline & & 1 & 2 & 3 & 4 & 5 \\
\hline reval & 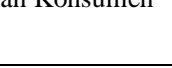 & Suka & Harap & Netral & Toleransi & $\begin{array}{l}\text { Tidak } \\
\text { Suka }\end{array}$ \\
\hline \multirow{5}{*}{ 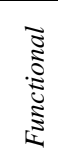 } & 1. Suka & $Q$ & A & A & A & $\mathrm{O}$ \\
\hline & 2. Harap & $\mathrm{R}$ & $\mathrm{I}$ & $\mathrm{I}$ & $\mathrm{I}$ & $\mathrm{M}$ \\
\hline & 3. Netral & $\mathrm{R}$ & I & I & I & M \\
\hline & 4. Toleransi & $\mathrm{R}$ & $\mathrm{I}$ & $\mathrm{I}$ & $\mathrm{I}$ & M \\
\hline & 5. Tidak Suka & $\mathrm{R}$ & $\bar{R}$ & $\mathrm{R}$ & $\mathrm{R}$ & $\mathrm{Q}$ \\
\hline
\end{tabular}

Keterangan:

$\mathrm{Q}=$ Questionable (Diragukan)

$\mathrm{R}=$ Reserve (Kemunduran)

$\mathrm{A}=$ Attractive (Menarik)

$\mathrm{I}=$ Indefferent (Netral)

$\mathrm{O}=$ One dimensional (Satu ukuran)

$\mathrm{M}=$ Must be (Keharusan)
3. Penetuan kategori untuk setiap variabel atau Kano's Weight digunakan aturan pada Blauth's formula (Walden, 1993) dalam Jaayanti dan Singgih, 2012), yakni: a) jika jumlah nilai (one dimensional + attractive + must be) $>$ jumlah nilai (indifferent + reserve + questionable) maka grade diperoleh nilai paling maksimum dari (one dimensional + attractive + must be), b) jika jumlah nilai (one dimensional + attractive + must be) < jumlah nilai (indifferent + reserve + questionable) maka grade diperoleh yang paling maksimum dari (indifferent + reserve + questionable), c) jika jumlah nilai (one dimensional + attractive + must be) $=$ jumlah nilai (indifferent + reserve + questionable) maka grade diperoleh yang paling maksimum diantara semua kategori kano yaitu (one dimensional, attractive, must be dan indifferent, reserve, questionable).

4. Menghitung nilai better dan worse. Better mengindikasikan seberapa banyak kenaikan kepuasan pelanggan jika kita menyediakan fiturnya (A\&O). Worse mengindikasikan seberapa banyak penurunan kepuasan pelanggan jika kita tidak menyediakan fiturnya (O\&M). adapun rumus untuk menghitung Worse dan Better adalah sebagai berikut:

$$
\begin{aligned}
& \text { Better }=\frac{A+O}{A+O+M+I} \\
& \text { Worse }=\frac{O+M}{A+O+M+I}
\end{aligned}
$$

5. Merumuskan tindakan perbaikan.

\section{HASIL DAN PEMBAHASAN}

\section{Analisis Model Kano}

Metode Kano merupakan langkah awal dalam melakukan pengolahan data 
dengan cara mencocokkan jawaban responden terhadap pertanyaan fungsional dan pertanyaan disfungsional yang kemudian dianalisis dan mengkategorikan jawaban responden ke dalam kategori kano. Setalah itu, jawaban tersebut dipetakan dengan kategori kano, di mana penetapan kategori berdasarkan jawaban responden dapat dilihat pada tabel 2 berikut:

\section{Tabel 2. Evaluasi Kualitas Model Kano}

\begin{tabular}{|c|c|c|}
\hline No. & Atribut & Grade \\
\hline 1 & $\begin{array}{l}\text { Kurikulum berorientasi pada } \\
\text { keragaman bidang ilmu, } \\
\text { teknologi, bidang keterampilan, } \\
\text { serta bidang keahlian profesi. }\end{array}$ & $\mathbf{O}$ \\
\hline 2 & $\begin{array}{l}\text { Pengajaran sesuai dengan } \\
\text { Rencana Pembelajaran Semester } \\
\text { (RPS) }\end{array}$ & $\mathbf{O}$ \\
\hline 3 & $\begin{array}{l}\text { Buku ajar, bahan ajar / handouts } \\
\text { dapat dipahami dengan baik. }\end{array}$ & $\mathbf{O}$ \\
\hline 4 & $\begin{array}{l}\text { Dosen mematuhi jadwal } \\
\text { perkuiahan yang ditetapkan. }\end{array}$ & $\mathbf{O}$ \\
\hline 5 & $\begin{array}{l}\text { Dosen menguasai materi } \\
\text { pengajaran dengan baik. }\end{array}$ & $\mathbf{M}$ \\
\hline 6 & $\begin{array}{l}\text { Metode penilaian dan prosedur } \\
\text { penilaian dilakukan secara } \\
\text { transparan dan subyektif. }\end{array}$ & $\mathbf{O}$ \\
\hline 7 & Dosen menjalankan e-learning. & M \\
\hline 8 & $\begin{array}{l}\text { Mahasiswa dapat berinteraksi } \\
\text { dengan dosen diluar jam } \\
\text { perkuliahan dengan baik. }\end{array}$ & $\mathbf{O}$ \\
\hline 9 & $\begin{array}{l}\text { Sebagai pembimbing akademis, } \\
\text { dosen dapat membantu mahasiswa } \\
\text { dalam menyelesaikan masalah } \\
\text { perkuliahan. }\end{array}$ & $\mathbf{O}$ \\
\hline 10 & $\begin{array}{l}\text { Dosen dapat membimbing dalam } \\
\text { menyelesaikan Tugas Akhir / } \\
\text { Skripsi mahasiswa dengan baik }\end{array}$ & $\mathbf{O}$ \\
\hline 11 & $\begin{array}{l}\text { Mahasiswa ikut terlibat dalam } \\
\text { penelitian dosen. }\end{array}$ & A \\
\hline 12 & $\begin{array}{l}\text { Dosen melibatkan mahasiswa } \\
\text { dalam melaksanakan pengabdian } \\
\text { masyarakat. }\end{array}$ & $\mathbf{I}$ \\
\hline 13 & $\begin{array}{l}\text { Proses pengisian KRS online yang } \\
\text { sangat mudah bagi mahasiswa }\end{array}$ & $\mathbf{O}$ \\
\hline
\end{tabular}

\begin{tabular}{|c|c|c|}
\hline No. & Atribut & Grade \\
\hline 14 & $\begin{array}{l}\text { Informasi akademik mudah } \\
\text { diperoleh, cepat, dan akurat. }\end{array}$ & $\mathbf{O}$ \\
\hline 15 & $\begin{array}{l}\text { Prosedur pendaftaran dan } \\
\text { pembayaran uang perkuliahan } \\
\text { jelas }\end{array}$ & $\mathbf{O}$ \\
\hline 16 & $\begin{array}{l}\text { Seleksi calon mahasiswa baru } \\
\text { dilaksanakan secara selektif dan } \\
\text { cepat }\end{array}$ & $\mathbf{O}$ \\
\hline 17 & $\begin{array}{l}\text { Staff administrasi akademik } \\
\text { berpakaian rapi }\end{array}$ & $\mathbf{A}$ \\
\hline 18 & $\begin{array}{l}\text { Staff administrasi akademik } \\
\text { handal/cepat tanggap dalam } \\
\text { memberikan pelayanan }\end{array}$ & $\mathbf{O}$ \\
\hline 19 & $\begin{array}{l}\text { Staff administrasi akademik } \\
\text { melayani dengan tulus hati, } \\
\text { ramah, dan sabar }\end{array}$ & $\mathbf{O}$ \\
\hline 20 & $\begin{array}{l}\text { Fasilitas kelas (meja, kursi, papan } \\
\text { tulis, pendingin ruangan, infocus) } \\
\text { memadai }\end{array}$ & $\mathbf{O}$ \\
\hline 21 & Fasilitas kesehatan memadai & $\mathbf{O}$ \\
\hline 22 & $\begin{array}{l}\text { Fasilitas kegiatan olahraga } \\
\text { memadai }\end{array}$ & $\mathbf{M}$ \\
\hline 23 & $\begin{array}{l}\text { Fasilitas perpustakaan yang } \\
\text { memadai (buku, jurnal } \\
\text { proceeding, dan artikel) }\end{array}$ & $\mathbf{O}$ \\
\hline 24 & Tersedianya akses e-library & $\mathbf{M}$ \\
\hline 25 & $\begin{array}{l}\text { Lingkungan kampus bersih aman } \\
\text { (ada security dan cctv) }\end{array}$ & $\mathbf{O}$ \\
\hline 26 & Kemudahan akses internet & $\mathbf{O}$ \\
\hline 27 & Labor komputer yang memadai & $\mathbf{O}$ \\
\hline 28 & Ketersediaan sarana parkir & $\mathbf{O}$ \\
\hline 29 & $\begin{array}{l}\text { Penguasaan ilmu dan } \\
\text { keterampilan }\end{array}$ & $\mathbf{A}$ \\
\hline 30 & $\mathrm{IPK}>3.00$ & $\mathbf{M}$ \\
\hline 31 & $\begin{array}{l}\text { Pengalaman praktek kerja } \\
\text { lapangan/magang }\end{array}$ & $\mathbf{A}$ \\
\hline 32 & Kemampuan berorganisasi & $\mathbf{O}$ \\
\hline 33 & $\begin{array}{l}\text { Kemampuan penggunaan } \\
\text { teknologi }\end{array}$ & $\mathbf{O}$ \\
\hline 34 & Kemampuan berbahasa inggris & $\mathbf{O}$ \\
\hline 35 & $\begin{array}{l}\text { Kemampuan berbahasa asing } \\
\text { (selain bahasa inggris) }\end{array}$ & $\mathbf{M}$ \\
\hline
\end{tabular}

Sumber: Data Olahan, 2019 
Tabel diatas menunjukkan bahwa Grade O (One Dimensional) merupakan atribut sangat penting yang perlu diprioritaskan oleh pihak manajemen perguruan tinggi karena tingkat kepuasan mahasiswa berhubungan linier dengan kinerja atribut. Jika perguruan tinggi menyediakan/memperhatikan atribut tersebut mkaa kepuasan mahasiswa akan meningkat, sebaliknya jika perguruan tinggi tidak menyediakan atau tidak memperhatikan atribut tersebut maka akan menyebabkan penurunan kepuasan mahasiswa. Adapun atribut yang termasuk ketegori $\mathrm{O}$ berjumlah 24 atribut.

Pada Grade A (Attractive) terdapat 4 atribut maknanya atribut yang masuk kedalam kategori ini perlu dipertahankan karena tingkat kepuasan mahasiswa kan menjadi sangat tinggi dengan meningkatnya kinerja atribut. Akan tetapi. Penurunan kinerja atribut tidak akan menyebabkan penurunan tingkat kepuasan mahasiswa.

Selanjutnya pada Grade M (Must be) terdapat 6 atribut di mana atribut yang berada pada kategori ini masih dianggap perlu oleh mahasiswa karena mahaisswa menjadi tidak puas apabila kinerja atribt yang bersangkutan rendah.

Grade I (Indifferent) hanya terdapat satu (1) atribut di mana atribut yang berada pada kategori ini merupakan atribut yang kurang diperhatikan oleh mahasiswa sehingga ada atau tidaknya atribut tersebut tidak akan berpengaruh terhadap kenaikan atau penurunan tngkat kepuasan mahasiswa.

\section{Analisis Respon Teknis}

Respon teknis ini didapatkan dengan cara melakukan diskusi dengan pihak manajemen perguruan tinggi yang lebih tinggi dibanding dengan perguruan tinggi yang diteliti sebagai benchmarking. Dari hasil diskusi didapatkan beberapa respon teknis yang dapat diambil yaitu:

1. Pengembangan dosen melalui pelatihan/seminar

2. Evaluasi dan pengembangan kurikulum berdasarkan KKNI

3. Monitoring proses pembelajaran

4. Memberikan pelatihan dan pengembangan softskill kepada staff akademik

5. Monitoring aturan akademik

6. Penambahan koleksi buku/jurnal atau e-book/e-journal

7. Peningkatan fasilitas internet

8. Bekerjasama dengan dunia usaha

\section{Analisis Prioritas Kebutuhan}

Analisis prioritas kebutuhan dibutuhkan untuk memperoleh nilai adjusted importance yang digunakan untuk memperoleh nilai prioritas respon teknis yang diperlukan oleh pihak manajemen perguruan tinggi dalam memperbaiki dan meningkatkan kualitas. Hasil analisis prioritas kebutuhan dapat dilihat pada tabel berikut:

Tabel 3. Hasil Analisis Prioritas Kebutuhan

\begin{tabular}{|c|c|c|c|c|c|}
\hline No & Atribut & $\begin{array}{l}\text { Bobot } \\
\text { Kano }\end{array}$ & Kepentingan & GAP & $\begin{array}{c}\text { Adjusted } \\
\text { Importance }\end{array}$ \\
\hline 1 & $\begin{array}{l}\text { Proses } \\
\text { pengisian } \\
\text { KRS online } \\
\text { yang sangat } \\
\text { mudah bagi } \\
\text { mahasiswa }\end{array}$ & 2 & 4,56 & $-1,43$ & 13,08 \\
\hline 2 & $\begin{array}{l}\text { Informasi } \\
\text { akademik } \\
\text { mudah } \\
\text { diperoleh, } \\
\text { cepat, dan } \\
\text { akurat. }\end{array}$ & 2 & 4,51 & $-0,95$ & 8,58 \\
\hline 3 & $\begin{array}{l}\text { Staff } \\
\text { administrasi } \\
\text { akademik } \\
\text { handal/cepat } \\
\text { tanggap } \\
\text { dalam } \\
\text { memberikan } \\
\text { pelayanan }\end{array}$ & 2 & 4,48 & $-1,00$ & 8,96 \\
\hline 4 & $\begin{array}{l}\text { Fasilitas } \\
\text { kesehatan } \\
\text { memadai }\end{array}$ & 2 & 4,36 & $-1,17$ & 10,23 \\
\hline
\end{tabular}




\begin{tabular}{clcccc}
\hline No & \multicolumn{1}{c}{ Atribut } & $\begin{array}{c}\text { Bobot } \\
\text { Kano }\end{array}$ & Kepentingan & GAP & $\begin{array}{c}\text { Adjusted } \\
\text { Importance }\end{array}$ \\
\hline 5 & $\begin{array}{l}\text { Fasilitas } \\
\text { perpustakaan } \\
\text { yang }\end{array}$ & 2 & 4,61 & $-0,91$ & 8,43 \\
& & & & \\
& $\begin{array}{l}\text { memadai } \\
\text { (buku, jurnal } \\
\text { proceeding, } \\
\text { dan artikel) }\end{array}$ & & & & \\
6 & $\begin{array}{l}\text { Kemudahan } \\
\text { akses } \\
\text { internet }\end{array}$ & 2 & 4,62 & $-1,34$ & 12,41 \\
7 & 2 & 4,46 & $-0,96$ & 8,58 \\
$\begin{array}{l}\text { Labor } \\
\text { komputer } \\
\text { yang } \\
\text { memadai }\end{array}$ & & & & \\
\hline
\end{tabular}

Sumber: Data Olahan, 2019

\section{Analisis Prioritas Respon Teknis}

Prioritas respon teknis didapatkan dengan cara mengalikan adjusted importance dengan nilai pada matriks hubungan antara kebutuhan konsumen dan respon teknis. Pada matriks hubungan, hubungan sangat kuat bernilai sembilan, hubungan kuat bernilai tiga dan hubungan lemah bernilai satu. Hasil analisis prioritas teknis yang diperoleh dapat dilihat pada tabel di bawah ini :

\section{Tabel 4. Analisis Prioritas Respon Teknis}

\begin{tabular}{clcc}
\hline No & \multicolumn{1}{c}{ Respon Teknis } & Prioritas & \% \\
\hline 1 & $\begin{array}{l}\text { Pengembangan dosen } \\
\text { melalui pelatihan/seminar }\end{array}$ & 25,29 & 2,72 \\
2 & $\begin{array}{l}\text { Evaluasi dan } \\
\text { pengembangan kurikulum } \\
\text { berdasarkan KKNI }\end{array}$ & 25,74 & 2,77 \\
3 & $\begin{array}{l}\text { Monitoring proses } \\
\text { pembelajaran }\end{array}$ & 200,91 & 21,62 \\
4 & $\begin{array}{l}\text { Memberikan pelatihan dan } \\
\text { pengembangan softskill }\end{array}$ & 80,64 & 8,68 \\
& $\begin{array}{l}\text { kepada staff akademik } \\
\text { Monitoring aturan } \\
\text { akademik }\end{array}$ & 203,9 & 21,94 \\
6 & $\begin{array}{l}\text { Penambahan koleksi } \\
\text { buku/jurnal atau e-book/e- }\end{array}$ & 75,87 & 8,17 \\
journal & $\begin{array}{l}\text { Peningkatan fasilitas } \\
\text { internet }\end{array}$ & 306,63 & 33,00 \\
\hline
\end{tabular}

\begin{tabular}{llcc}
\hline No & Respon Teknis & Prioritas & $\%$ \\
\hline 8 & $\begin{array}{l}\text { Bekerjasama dengan dunia } \\
\text { usaha }\end{array}$ & 10,23 & 1,10 \\
\hline \multicolumn{2}{l}{ Sumber: Data Olahan, 2019 } \\
\end{tabular}

Berdasarkan hasil perhitungan prioritas, diperoleh tiga (3) yang menjadi prioritas respon teknis yang harus dilakukan oleh manajemen perguruan tinggi demi memenuhi kebutuhan mahasiswa. Respon teknis yang diprioritaskan atas dasar pertimbangan bahwa nilai persentase ke delapan respon teknis ini melebihi rata-rata seluruh persentase respon teknis (Singh., 2008). Diantara respon teknis yang akan diprioritaskan yaitu dengan monitoring proses pembelajaran, monitoring aturan akademik, dan peningkatan fasilitas internet.

\section{Perancangan House of Quality (HOQ)}

Untuk membuat House of Quality maka diperlukan prioritas kebutuhan dan prioritas respon teknis yang kemudian dihubungan melalui matriks yang ditunjukkan oleh gambar berikut:

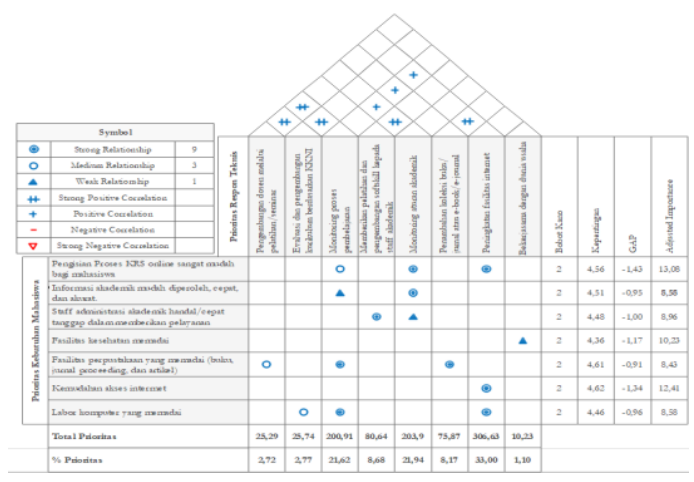

Gambar 1. House of Quality

Gambar tersebut menunjukkan matriks hubungan antara prioritas kebutuhan mahasiswa dengan prioritas respon teknis di mana simbol menunjukkan hubungan yang kuat dengan jumlah nilai 9 , simbol 
menunjukkan hubungan yang menengah dengan jumlah nilai 3 , dan simbol menunjukkan hubungan yang kemah dengan nilai 1. Struktur prioritas kebutuhan pelanggan adalah komponen kunci HoQ. Serangkaian prioritas kebutuhan pelanggan akan berdampak besar pada kegiatan pengembangan produk selanjutnya. Dalam matriks HoQ, matriks tersebut menjelaskan beberapa prioritas kebutuhan mahasiswa yang dapat digunakan sebagai titik perbaikan yang harus dilakukan oleh Perguruan Tinggi swasta sebagai berikut:

1. Proses belajar mahasiswa yang efektif dimulai dari pengisian Kartu Rencana Studi (KRS) saat memulai perkuliahan di awal semester. Oleh itu, penting bagi Perguruan Tinggi Swasta mempersiapkan jadwal perkuliahan dan menginput jadwal tersebut melalui sistem sebelum perkuliahan dimulai. Selain itu, pihak perguruan tinggi harus memastikan bahwa server mereka kuat sehingga server dapat menampung jumlah pengunjung/mahasiswa yang mengakses saat pengisian KRS secara online.

2. Bagi mahasiswa, sumber informasi yang berkaitan dengan proses perkuliahan mereka adalah hal penting yang mereka ketahui. Oleh itu, pihak perguruan tinggi harus mengupdate portal masing masing fakultas di mana informasi yang berkaitan dengan akademik dapat diperoleh dengan cepat oleh mahasiswa. Selain itu, perguruan tinggi juga dapat menyebarkan informasi melalui majalah dinding pada fakultas masing-masing.

3. Perguruan tinggi dapat menerapkan IT/ICT dalam manajemen mutu layanan untuk meningkatkan efesiensi dan memberikan kemampuan pelayanan yang cepat, meningkatkankan kualifikasi SDM sesuai dengan kebutuhan pelayanan pendidikan di perguruan tinggi, pihak perguruan tinggi harus membuat SOP bagi staff akademik sehingga tidak ada lagi pelayanan yang tidak sesuai dengan standarnya.

4. Perlu adanya terutama fasilitas kesehatan sehingga memudahkan dosen, tenaga kependidikan, dan mahasiswa dalam melakukan konsultasi kepada dokter jika diperlukan. Perguruan tinggi juga dapat melakukan kerjasama dengan berbagai rumah sakit.

5. Fasilitas buku maupun jurnal yang lengkap serta up to date harus ada disediakan oleh perguruan tinggi sehingga mahasiswa mudah mendapatkan informasi yang mereka perlukan, hal ini dapat membuat proses belajar menjadi efektif. Selain itu perguruan tinggi swasta harus mempunyai lisensi atau berlangganan yang dapat mendownload/mengunduh jurnal internasional atau buku yang sifatnya berbayar.

6. Saat ini internet merupakan kebutuhan bagi dosen dan mahasiswa dalam proses pembelajaran. Beberapa dosen telah menggunakan e-learning sebagai proses belajar mengajar sehingga internet atau server perguruan tinggi swasta harus kuat sehingga dalam proses pembelajaran menjadi lebih efektif. 
7. Beberapa mata kuliah dalam perguran tinggi membutuhkan komputer sebagai sarana belajar. Hal itu yang menjadikan Perguruan Tinggi harus memiliki labor komputer dan memastikan bahwa komputer tersebut masih layak digunakan dan ter up to date sehingga dalam proses pembelajaran akan menjadi efektif.

\section{PENUTUP}

\section{Kesimpulan}

Quality Function Deployment (QFD) dengan mengintegrasikan model kano merupakan salah satu alat kualitas yang dapat digunakan untuk mengoptimalkan kualitas pelayanan saat ini terhadap Perguruan Tinggi Swasta. Matriks House of Quality (HoQ) memperoleh beberapa poin untuk mengoptimalkan kualitas yang dapat diimplementasikan di Perguruan Tinggi Swasta seperti: monitoring proses pembelajaran, monitoring aturan akademik, dan peningkatan fasilitas internet.

\section{Saran}

Manajemen perguruan tinggi dapat menetapkan standar kualitas untuk memastikan bahwa apa yang menjadi kebutuhan mahasiswa dapat dipenuhi untuk memenuhi kepuasan mahasiswa. Adapun atribut yang menjadi prioritas kebutuhan mahasiswa yakni Proses pengisian KRS online yang sangat mudah bagi mahasiswa, Informasi akademik mudah diperoleh, cepat, dan akurat, Staff administrasi akademik handal/cepat tanggap dalam memberikan pelayanan, Fasilitas kesehatan memadai, Fasilitas perpustakaan yang memadai (buku, jurnal proceeding, dan artikel), Kemudahan akses interrnet, dan Labor komputer yang memadai.

\section{DAFTAR PUSTAKA}

Al-Bashir, A. (2016). Applying total quality management tools using qfd at higher education institutions in gulf area (Case study: ALHOSN University). International Journal of Production Management and Engineering, 4(2), 87-98.

Qureshi, M. I., Janjua, S. Y., Zaman, K., Lodhi, M. S., \& Tariq, Y. B. (2014). Internationalization of higher education institutions: implementation of DMAIC cycle. Scientometrics, 98(3), 2295-2310.

Arefi, M., Heidari, M., Morkani, G. S., \& Zandi, K. (2012). Application of Kano Model in higher education quality improvement: Study master's degree program of educational psychology in State Universities of Tehran. World Applied Sciences Journal, 17(3), 347-353.

Suhendar, E. (2015). Penerapan Metode Quality Function Deployment (QFD) Dalam Upaya Peningkatan Kualitas Pelayanan Akademik Pada Ub. Faktor Exacta,7(4), 372-386.

Sunder M, V., \& Antony, J. (2018). A conceptual Lean Six Sigma framework for quality excellence in higher education institutions. International Journal of Quality \& Reliability Management, 35(4), 857-874.

Bangun, A., Ginting, R., \& Tarigan, U. (2013). Analisis Kualitas Pelayanan Jasa Pendidikan dengan Menggunakan Quality Function Deployment di Jurusan Akuntansi Xyz.Jurnal Teknik Industri USU, 3(1). 
Ngurah, Gusti J.,A \& Putu, S.,E.,P. (2016). Assessment of Service Quality in Higher Education: Case Study in Private University. International Journal of Business and Management Invention 5(9), September, 82-88.

Yang, C. C., Sukwadi, R., \& Mu, P. P. (2010). Integrating kano model into customer-oriented reputation model in higher education. In 2010 International Conference on Management and Service Science (pp. 1-4). IEEE.

Singh, V., \& Kumar, A. (2008). Evaluation of quality in an educational institute: a quality function deployment approach. Educational Research and Reviews, 3(4), 162-168. 